\title{
Antioxidant and Antiaging Assays of Ageratum conyzoides (L.) Ethanolic Extract
}

\author{
Afifah B. Sutjiatmo ${ }^{1 *}$, Novi Edriayani ${ }^{1}$, Tira Endang Mulyasari ${ }^{1}$, Faizal Hermanto ${ }^{1}$, M. Fahrauk ${ }^{1}$, \\ Elin Y. Sukandar ${ }^{2}$, Hanna Sari Widya Kusuma ${ }^{3}$, Rizal Rizal ${ }^{3,4}$, Wahyu Widowati ${ }^{5 *}$ \\ ${ }^{1}$ Faculty of Pharmacy, University of Jenderal Achmad Yani, Cimahi, West Java, Indonesia \\ ${ }^{2}$ School of Pharmacy, Bandung Institute of Technology, Bandung, West Java, Indonesia \\ ${ }^{3}$ Biomolecular Biomedical Research Center, Aretha Medika Utama, Bandung, West Java, Indonesia \\ ${ }^{4}$ Department of Electrical Engineering, Faculty of Engineering, Universitas Indonesia, Depok, West Java, Indonesia \\ ${ }^{5}$ Faculty of Medicine, Maranatha Christian University, Bandung, West Java, Indonesia
}

\begin{abstract}
The declining ability of tissues to repair or replace themselves and maintain their structure and normal function is called aging. Aging is caused by free radical that can induce the activation of elastase and collagenase. Ageratum conyzoides (L.) or known as Babadotan is a medicinal plant that has been reported to be a good source of antioxidants that also inhibit aging process. The purpose of this research is to evaluate the antioxidant and antiaging properties of Babadotan Ethanolic Extract (BEE). Franswoth method was used to determine the phytochemical assay of BEE. Measurement of 2,2-diphenyl 1-picrylhydrazyl (DPPH) scavenger was used for antioxidant assay, and inhibitory of elastase and collagenase activities was used for antiaging assay. The analysis of phytochemical compounds exhibited the presence of flavonoids, alkaloids, tannins, polyphenols, steroids and triterpenoids, monoterpenoids and terpenoids, and the absence of saponin. BEE has lower activity on DPPH scavenging activity $\left(\mathrm{IC}_{50}=80.7 \mu \mathrm{g} / \mathrm{mL}\right)$ than quercetin $\left(\mathrm{IC}_{50}=3.25 \mu \mathrm{g} / \mathrm{mL}\right)$. BEE exhibited lower elastase and collagenase inhibitory activity $\left(\mathrm{IC}_{50}=45.35 \pm 2.2 \mu \mathrm{g} / \mathrm{mL}\right.$ and $55.07 \pm 1.1 \mu \mathrm{g} / \mathrm{mL}$, respectively) compared to quercetin $\left(\mathrm{IC}_{50}=11.64 \pm 0.67 \mu \mathrm{g} / \mathrm{mL}\right.$ and $\left.19.91 \pm 0.46 \mu \mathrm{g} / \mathrm{mL}\right)$. Overall, BEE possesses antioxidant and antiaging activities, although the activities are lower than quercetin.
\end{abstract}

Keywords : antioxidant; antiaging; babadotan; quercetin; collagenase

*corresponding author

Email:afifah@lecture.unjani.ac.id,wahyu_w60@yahoo.com

\section{INTRODUCTION}

The aging process is a physiological process that will occur in all living things, including all organs and skin. Naturally, every human being wants to look young, but the aging process will happen slowly and the skin is one of the body's tissues that directly shows the aging process. Although aging is something that must happen, the effort to prevent it never subsides. Various ways can be done to keep the skin healthy and young (Adam, 2005). Collagen and elastin are biomaterials that make up the dermis layer which plays an important role in the body, such as to repair and rebuild connective tissue (Widowati et al., 2018).

Under normal conditions, the skin produces enzymes such as elastase. Reactive oxygen species (ROS) or excessive exposure to ultraviolet (UV) light will accelerate the activation process of the elastase enzyme that can degrade elastin. Elastin is a major component of connective tissue elastic fibers. Elastic fibers on the skin, together with collagen fibers, form a tissue under the epidermis. Activation of the elastase enzyme will attack all major connective tissue matrix proteins, including elastin, which will lead to shrinkage of the skin (Kim et al., 2007; Mukherjee et al., 2011).

Antioxidant treatment may be useful for protecting the skin from aging (Taniguchi, 2012). Bioactive compounds as antioxidants from the plant have been widely studied to prevent aging. Various plants have been known to have activities as antioxidants that can prevent aging such as green tea, grape seeds, ginger (Cai et al., 2004), Oryza sativa (Widowati et al., 2016), Hibiscus sabdariffa (Widowati et al., 2017), and Jasminum sambac (Widowati et al., 2018).

Ageratum conyzoides or known as babadotan is a plant that is widely grown in Indonesia and has been used since ancient times in the field of medicine. Babadotan plants are traditionally used for wound healing. According to a study, the ethanol extract of babadotan leaves with a concentration of $3 \%, 5 \%$, and $7 \%$ can accelerate the process of wound healing and density of collagen fibers (Afrianti et al., 2014). 
Ethanol extract of babadotan leaves with a concentration of $15 \%$ can accelerate the growth of collagen fibers, where the density of collagen fibers occurs on the $11^{\text {th }}$ day of treatment (Afrianti et al., 2014). Babadotan plants also have antioxidant activities that can inhibit aging. The study stated that babadotan plants had antioxidant activity of free radical scavenging with $\mathrm{IC}_{50}$ value of $46.01 \pm 2.23 \mu \mathrm{g} / \mathrm{mL}$ (Nasrin, 2013).

The active compounds contained in babadotan are flavonoids, alkaloids, chromenes, benzofuran, and pentenoids. The highest content of active compounds in babadotan is flavonoids, especially quercetin. Quercetin, a flavonol compound, has antioxidant activity and is widely explored for therapeutic use of babadotan (Galati et al., 2008; Tambunan et al., 2017). Other studies say that quercetin has anti-collagenase activity (Bougeois et al., 2016). Therefore, this study aims to examine the antioxidant and antiaging activity of babadotan ethanolic extract (BEE) compared to quercetin.

\section{MATERIAL AND METHODS}

\section{Preparation of BEE}

The plants of $A$. conyzoides were collected from Kebun Percobaan Manoko Lembang, Bandung, West Java, Indonesia. The plants were determinated at Tissue Culture Laboratory, Departement of Biology, Padjajaran University, Bandung, West Java, Indonesia. The dried simplicia of A.conyzoides (400 g) was sorted, extracted with distilled ethanol $70 \%$ by maceration method. The ethanol filtrate was filtered, and the obtained residues were re-macerated in triplicates until colourless filtrate was obtained. Then, the filtrate was dried using a rotary evaporator at $50^{\circ} \mathrm{C}$. The yield of BEE was $49.5 \mathrm{~g}$ and stored at $20^{\circ} \mathrm{C}$. The $\mathrm{BEE}$ was used in the experiment. Quercetin was used as a standard compound (Widowati et al., 2016; 2017; 2018).

\section{Qualitative Phytochemical Assay}

The phytochemical screening assay of BEE was evaluated by modified Farnsworth method to identify the presence of flavonoids, alkaloids, saponins, polyphenol, tannins, quinon, steroids and triterpenoids, monoterpenoids and sesquiterpenoids as listed below (Widowati et al., 2016, 2017, 2018; Siregar et al., 2019; Prahastuti et al., 2020; Farnsworth, 1966).

\section{Flavonoid Identification}

Sample of BEE ( $1 \mathrm{~g}$ ) was added into a beaker glass. After that, $100 \mathrm{~mL}$ of hot water was added to beaker glass, then the mixture was simmered for 5 minutes before being filtered. The obtained filtrate $(5 \mathrm{~mL})$ was inserted into a test tube. Magnesium powder [Merck EM105815, USA] and $1 \mathrm{~mL} 2 \mathrm{~N} \mathrm{HCl}$ were added to the test tube. The mixture in the test tube was heated before being filtered. After that, amyl alcohol was added to the $5 \mathrm{~mL}$ filtrate. A yellow to red colour will be formed if there were flavonoids in the mixture (Widowati et al., 2016, 2017, 2018; Siregar et al., 2019; Prahastuti et al., 2020).

\section{Alkaloid Identification}

Sample of BEE (1 g) was weighed and inserted into the mortar. Then, the sample was grounded with $5 \mathrm{~mL}$ of ammonia. Chloroform $20 \mathrm{~mL}$ was added to the mixture. The mixture was filtered and the obtained filtrate was put into a test tube. HCL $2 \mathrm{~N}$ was added to the test tube, which was subsequently shaken to form 2 layers. After that, the Dragendorf reagent was added to the test tube. An orange-brown precipitate will form when there are alkaloids in the mixture. (Widowati et al., 2016, 2017, 2018; Siregar et al., 2019; Prahastuti et al., 2020).

\section{Saponin Identification}

Sample of BEE $(1 \mathrm{~g})$ was put into a test tube, $10 \mathrm{~mL}$ of water was added, then the test tube was heated. The formed foam was observed (positive saponin if $1 \mathrm{~cm}$ of foam was formed for 5-10 minutes) (Widowati et al., 2016, 2017, 2018; Siregar et al., 2019; Prahastuti et al., 2020).

\section{Tannin Identification}

Approximately $1 \mathrm{~g}$ of sample was placed in the test tube with $2 \mathrm{~mL}$ of HCl $2 \mathrm{~N}$ [Merck 1003171000], then heated for 30 minutes. The mixture was filtered and amyl alcohol [Merck 10979, USA] was added to the filtrate. The colour purple will be formed if there are tannins in the mixture (Widowati et al., 2016, 2017, 2018; Siregar et al., 2019; Prahastuti et al., 2020).

\section{Polyphenol Identification}

Sample of BEE (1 g) was heated with water. The mixture was filtered, and 2-3 drops of $1 \% \mathrm{FeCl}_{3}$ solution was added to the filtrate. The presence of polyphenols was characterized by the formation of blackish-blue (Widowati et al., 2016, 2017, 2018; Siregar et al., 2019; Prahastuti et al., 2020).

\section{Quinon Identification}

Briefly $1 \mathrm{~g}$ of sample was heated with water, then filtered. The filtrate was added with 2-3 drops of 5\% potassium hydroxide solution. The presence of quinones was characterized by the formation of red (Farnsworth, 1966).

\section{Steroid /triterpenoid Identification}

Approximately $1 \mathrm{~g}$ of sample was placed on the plate, then the sample was soaked with acetic acid for 10-15 minutes. One drop of absolute sulfate $\left(\mathrm{H}_{2} \mathrm{SO}_{4}\right)$ [Merck 109073, USA] was added to the sample. Steroids were indicated by green/blue formations, and triterpenoids were indicated by the formation of orange/red sediments 
(Widowati et al., 2016, 2017, 2018; Siregar et al., 2019; Prahastuti et al., 2020).

\section{Monoterpenoid and Sesquiterpenoid Identification}

Briefly $1 \mathrm{~g}$ of BEE was added with $20 \mathrm{~mL}$ ether, then filtered. The obtained filtrate was evaporated on the evaporating dish to dry. At the residue, 2-3 drops of 10\% vanillin reagent in concentrated sulfuric acid was added. The presence of monoterpenoids and sesquiterpenoids was characterized by the formation of colours (Farnsworth, 1966).

\section{2,2-Diphenyl-1-Picrylhydrazil (DPPH) Assay}

Method from Widowati et al. (2016) was used for the DPPH assay. The method is based on the formation of non-radical DPPH-H resulted from the addition of hydrogen from an antioxidant characterized by a reduction in alcoholic DPPH solution (Sohn et al., 2003). Briefly, $50 \mu \mathrm{L}$ various concentration of samples (BEE, quercetin), was introduced in 96-well microplate followed by addition of $200 \mu \mathrm{l}$ of $0.077 \mathrm{mmol} / \mathrm{L} \mathrm{DPPH}$ [Sigma Aldrich D9123, USA] into the well. The mixture was incubated at room temperature for $30 \mathrm{~min}$ in the dark. After that, absorbance was measured using a microplate reader [Multiskan ${ }^{\mathrm{TM}}$ GO Microplate Spectrophotometer, Thermo Scientific, USA] at $517 \mathrm{~nm}$. The scavenging activity (\%) was calculated as below:

\section{Scavenging Activity $(\%)=($ Ac - As $) /$ Ac x 100 \\ $\mathrm{Ac}=$ negative control absorbance (without samples) \\ As $=$ samples absorbance}

The scavenging activity (\%) was then continued to be calculated as median inhibitory concentration $\left(\mathrm{IC}_{50}\right)$ (Widowati et al., 2016; 2017; 2018).

\section{Collagenase Inhibitory Activity Assay}

Collagenase inhibitory assay was measured using previously modified method (Thring et al., 2009; Widowati et al., 2016; 2017; 2018; Utami et al., 2018). Mixed solution consisted of $60 \mu \mathrm{L}$ Tricine buffer (50 $\mathrm{mM}, \mathrm{pH}$, containing $10 \mathrm{mM} \mathrm{CaCl}$ and $400 \mathrm{mM}$ $\mathrm{NaCl}), 10 \mu \mathrm{L}$ collagenase enzyme from $C$. histolyticum [Sigma C8051] $(0.2 \mathrm{U} / \mathrm{mL}$ in cold aquadest) and $30 \mu \mathrm{L}$ of various level of sample $(0-1000 \mu \mathrm{g} / \mathrm{mL}$ for BEE, $0-1000 \mu \mathrm{M}$ for compounds) $(50 \mu \mathrm{g} / \mathrm{mL}, 25 \mu \mathrm{g} / \mathrm{mL}$, $12.50 \mu \mathrm{g} / \mathrm{mL}, 6.25 \mu \mathrm{g} / \mathrm{mL}, 3.13 \mu \mathrm{g} / \mathrm{mL}, 1.56 \mu \mathrm{g} / \mathrm{mL}$ and $0.78 \mu \mathrm{g} / \mathrm{mL}$ ) was prepared. Then, the solution was incubated in the orbital shaker for 20 minutes at $37^{\circ} \mathrm{C}$. Then, $20 \mu \mathrm{L}$ of N-[3-(2-Furyl)acryloyl]-leugly-Pro-Ala (FALGPA) [Sigma F5135] (col 1) substrate was added, then incubated for 20 minutes at $37^{\circ} \mathrm{C}$. The absorbance was measured of $345 \mathrm{~nm}$ (Multiskan ${ }^{\mathrm{TM}} \mathrm{GO}$ Microplate Spectrophotometer, Thermo Scientific) (Thring et al., 2009; Widowati et al., 2016; 2017; 2018; Utami et al., 2018). The collagenase inhibition activity is calculated using the formula:

Inhibitory Activity $(\%)=($ Ac $-A s) / A c x 100$

Ac $=$ negative control absorbance (without samples)

As $=$ samples absorbance

The median inhibitory concentration $\left(\mathrm{IC}_{50}\right)$ of collagenase assay were also calculated.

\section{Elastase Inhibitory Activity Assay}

Inhibitory activity of elastase was measured using previously modified method (Thring et al., 2009; Widowati et al., 2016; 2017; 2018; Utami et al., 2018). $10 \mu \mathrm{L}$ samples $(0.78-50 \mu \mathrm{g} / \mathrm{mL})$ was pre-incubated at $25^{\circ} \mathrm{C}$ for $15 \mathrm{~min}$ with $5 \mu \mathrm{L}$ elastase from porcine pancreas [Sigma 45124$](0.5 \mathrm{mU} / \mathrm{mL}$ in cold aquadest $)$ and $135 \mu \mathrm{L}$ Tris buffer (100 mM, pH 8, Pharmacia Biotech 17-1321-01). After preincubation, the mixture was then added with $10 \mu \mathrm{L} \mathrm{N}$-Sucanyl-Ala-Ala-Alap-Nitroanilide substrate [Sigma 54760] ( $2 \mathrm{mg} / \mathrm{mL}$ in Tris buffer), incubated at $25^{\circ} \mathrm{C}$ for $15 \mathrm{~min}$. Absorbance was measured at $410 \mathrm{~nm}$ wavelength (Multiskan $^{\mathrm{TM}}$ GO Microplate Spectrophotometer, Thermo Scientific, USA).

Inhibitory activity $(\%)=(\mathrm{Ac}-\mathrm{As}) / \mathrm{Ac} \times 100$

Ac: negative control absorbance (without sample)

As: sample absorbance

The median inhibitory concentration $\left(\mathrm{IC}_{50}\right)$ of elastase assay was also calculated.

Table 1. The result of qualitative phytochemical screening of BEE

\begin{tabular}{ll}
\hline Phytochemical content & BEE \\
\hline Phenols & + \\
Flavonoids & + \\
Triterpenoids/Steroids & + \\
Saponins & - \\
Tannins & + \\
Alkaloids & + \\
Quinons & + \\
Monoterpenoids and Sesquiterpenoids & + \\
\hline+ detected; - : Not detected &
\end{tabular}

\section{RESULTS}

\section{Phytochemical Screening of BEE}

Phytochemical screening of BEE was conducted to find out presence of phenols, flavonoids, triterpenoids and steroids, tannins, alkaloids, quinones, monoterpenoids 
and sesquiterpenoids. The result of BEE phytochemical screening was showed in Table 1. Phytochemical screening showed that phenols, flavonoids, triterpenoids and steroids, saponins, tannins, alkaloids, quinones, monoterpenoids and sesquiterpenoids were detected, while saponins were not detected.

\section{2,2 Diphenyl-1-Picrylhydrazil (DPPH) Assay}

Antioxidant capacity of BEE and quercetin was determined using DPPH free radical scavenging activity. The method was based on the formation of non-radical DPPH-H resulted from the addition of hydrogen from an antioxidant characterized by a reduction in alcoholic DPPH solution (Sohn et al., 2003). The antioxidant molecule quenched DPPH free radical, which was characterized by the changing of purple colour of DPPH sample to become colourless. The median Inhibitory Concentration $\left(\mathrm{IC}_{50}\right)$ could be seen in Table 2. As shown in Table 2, the $\mathrm{IC}_{50}$ value of BEE was higher $(80.7 \mu \mathrm{g} /$ $\mathrm{mL})$ than quercetin $(2.73 \mu \mathrm{g} / \mathrm{mL})$. These results indicate low scavenging activity of BEE compared to quercetin.

\section{Collagenase Inhibitory Activity Assay}

Collagenase activity assay was measured by a spectrophotometric method. Collagenase is the enzyme that degrade collagen, an important component of the skin. The collagenase inhibitory activity can be seen in Figure 1. The $\mathrm{IC}_{50}$ value of collagenase inhibitory activity of BEE and quercetin was shown in Table 3 . The inhibitory activity of BEE was comparable with quercetin. Figure 1. shows that collagenase activities of BEE (44.01 $\%)$ were lower than quercetin $(89.73 \%)$. However, as shown in Table $3, \mathrm{IC}_{50}$ value of BEE $(55.07 \pm 1,1 \mu \mathrm{g} / \mathrm{mL})$ was higher than quercetin $(19.91 \pm 0,46 \mu \mathrm{g} / \mathrm{mL})$. These findings indicate BEE has lower collagenase inhibitory activity compared to quercetin.

\section{Elastase Inhibitory Activity Assay}

The elastase inhibitory activity of BEE and quercetin were measured. The percentage of elastase inhibitory activity of BEE was shown in Figure 2. The elastase inhibitory activity of the highest concentration of BEE was lower $(53.99 \%)$ than quercetin $(115.36 \%)$. The $\mathrm{IC}_{50}$ value of elastase inhibitory activity of BEE and quercetin was

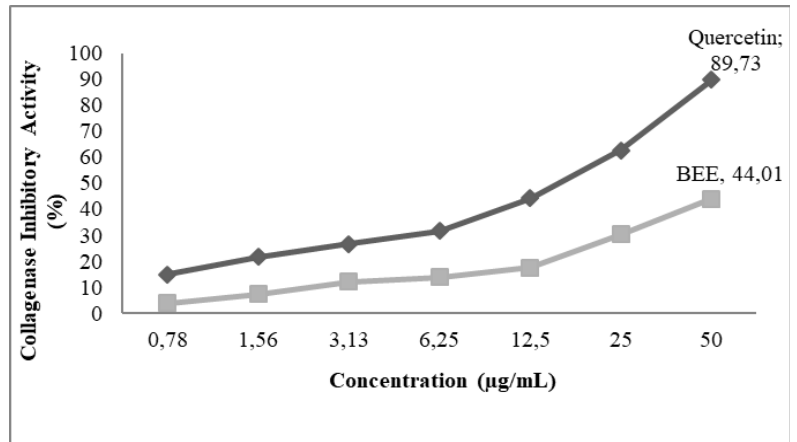

Figure 1. Collagenase inhibitory activity of BEE and quercetin (final concentration: $0.78 ; 1.56 ; 3.13 ; 6.25$; $12.5 ; 25$; and $50 \mu \mathrm{g} / \mathrm{mL}$ )

Table 2. The $\mathrm{IC}_{50}$ value of DPPH scavenging activity of BEE and quercetin

\begin{tabular}{lllll}
\hline Samples & Equation & $\mathbf{R}^{\mathbf{2}}$ & $\mathbf{I C}_{\mathbf{5 0}} \mu \mathrm{g} / \mathrm{mL}$ & $\mathbf{I C}_{\mathbf{5 0}}(\mu \mathrm{M})$ \\
\hline BEE & $\mathrm{y}=0.3811 \mathrm{x}+19.245$ & 0.996 & $80.7 \pm 10.09$ & - \\
Quercetin & $\mathrm{y}=15.63 \mathrm{x}+7.364$ & 0.991 & $2.73 \pm 0.24$ & $10.75 \pm 0.94$ \\
\hline
\end{tabular}

*Linear equations, coefficient of regression $\left(\mathrm{R}^{2}\right)$ and $\mathrm{IC}_{50}$ of each sample were calculated. $\mathrm{IC}_{50}$ of $\mathrm{BEE}$ was presented in $\mu \mathrm{g} / \mathrm{mL}$, while quercetin were presented in $\mu \mathrm{M}$ and $\mu \mathrm{g} / \mathrm{mL}$.

Table 3. The $\mathrm{IC}_{50}$ value of collagenase inhibitory activity of BEE and uercetin

\begin{tabular}{lllll}
\hline Samples & Equation & $\mathbf{R}^{\mathbf{2}}$ & IC $_{\mathbf{5 0}} \mu \mathrm{g} / \mathrm{mL}$ & $\mathbf{I C}_{\mathbf{5 0}}(\mu \mathrm{M})$ \\
\hline BEE & $\mathrm{y}=0.7707 \mathrm{x}+7.558$ & 0.9623 & $55.07 \pm 1.1$ & - \\
Quercetin & $\mathrm{y}=1.4522 \mathrm{x}+21.086$ & 0.9696 & $19.91 \pm 0.46$ & $65.93 \pm 1.53$
\end{tabular}

*Linear equations, coefficient of regression $\left(\mathrm{R}^{2}\right)$ and $\mathrm{IC}_{50}$ of each sample were calculated. $\mathrm{IC}_{50}$ of $\mathrm{BEE}$ was presented in $\mu \mathrm{g} / \mathrm{mL}$, while quercetin were presented in $\mu \mathrm{M}$ and $\mu \mathrm{g} / \mathrm{mL}$.

Table 4. The $\mathrm{IC}_{50}$ value of elastase inhibitory activity of BEE and quercetin

\begin{tabular}{lllll}
\hline Samples & Equation & $\mathbf{R}^{\mathbf{2}}$ & $\mathbf{I C}_{\mathbf{5 0}} \mu \mathrm{g} / \mathrm{mL}$ & $\mathbf{I C}_{\mathbf{5 0}}(\mu \mathrm{M})$ \\
\hline BEE & $\mathrm{y}=0.7914 \mathrm{x}+14.105$ & 0.975 & $45.35 \pm 2.2$ & - \\
Quercetin & $\mathrm{y}=1.6216 \mathrm{x}+31.454$ & 0.9873 & $11.44 \pm 0.67$ & $37.84 \pm 1.4$ \\
\hline
\end{tabular}

*Linear equations, coefficient of regression $\left(\mathrm{R}^{2}\right)$ and $\mathrm{IC}_{50}$ of each sample were calculated. $\mathrm{IC}_{50}$ of $\mathrm{BEE}$ was presented in $\mu \mathrm{g} / \mathrm{mL}$, while quercetin were presented in $\mu \mathrm{M}$ and $\mu \mathrm{g} / \mathrm{mL}$. 
shown in Table 4. The $\mathrm{IC}_{50}$ value of elastase inhibitory of quercetin $(11.44 \pm 0.67 \mu \mathrm{g} / \mathrm{mL})$ was lower than BEE $(45.35 \pm 2.2 \mu \mathrm{g} / \mathrm{mL})$. The result shows that BEE posseses lower elastase inhibition activity compared to quercetin.

\section{DISCUSSION}

Phytochemical screening is a qualitative analysis carried out by observing the colour changes. Table 1. showed that the results of phytochemical tests on BEE positively contained flavonoids, alkaloids, tannins, polyphenols, monoterpenesquiterpenes, steroids-triterpenoids, and quinones, while the saponin content in BEE was

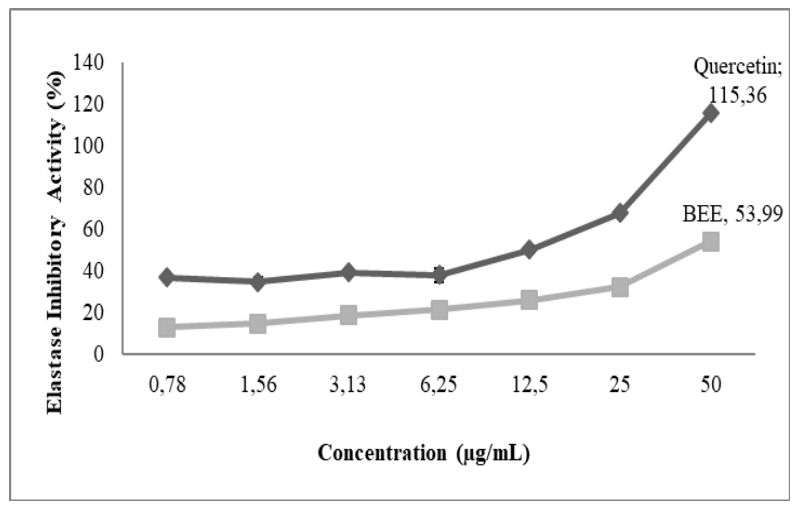

Figure 2. Elastase inhibitory activity of BEE and quercetin (final concentration: $0.78 ; 1.56 ; 3.13 ; 6.25$; $12.5 ; 25$; and $50 \mu \mathrm{g} / \mathrm{mL}$ )

negative. The previous study of phytochemical content of Babadotan ethanol extract (A. conyzoides L.) showed no saponins (Wuyep et al., 2017). The active compounds contained in babadotan herbs include alkaloids, flavonoids, tannins, glycosides, minerals, steroids, coumarins, chromens, terpenoids, phenols and various other compounds (Amadi et al., 2012).

Babadotan has high flavonoid compounds. Flavonoids are phenolic compounds that have the potential to be antioxidants because they can prevent the development of free radicals in the body while repairing damaged body cells and can prevent aging by inhibiting factors that can accelerate aging. The presence of terpenoids in BEE has the potential to also act as an antioxidant because terpenoids can donate Hydrogen $(\mathrm{H})$ atoms so that they can convert free radicals to reactive. This result was supported by previous research that the major compound of terpenoids in Thuidium tamariscellum extract had high antioxidant property by DPPH radical scavenging, $\mathrm{ABTS}^{+}$radical scavenging, hydrogen peroxide radicals scavenging, FRAP assay, and metal chelating activity (Mohanmedas \& Kumaraswamy, 2018).

Reactive Oxygen Species (ROS) play an important role in the aging process. Therefore, antioxidants are used for the prevention of aging. Excessive production of ROS and oxidative stress were caused by UV radiation which is absorbed by the skin continuously. Oxidative damage caused other damage too, including modifying proteins and genes that alter the structure and function of proteins (Irshad et al., 2002). Excessive ROS level will result in the activation of collagenase and elastase, which contribute to the skin aging (Mukherjee et al., 2011).

Research on active compounds derived from plants has been carried out and some plants have been found to have anti-collagenase and anti-elastase activity, like white tea, green tea, and cleavers. Anti-colagenase and anti-elastase activities are caused by the presence of various phenolic compounds such as flavonoids derived from these plants (Thring et al., 2009).

The anti-elastase activity of BEE showed that BEE could potentially inhibit the elastase enzyme in degrading elastin compared to the negative control group because of the large amount of secondary metabolites present in BEE. The previous research reported that Babadotan has antioxidant activity with $\mathrm{DPPH} \mathrm{IC}_{50}$ value of $46.01 \pm$ $2.23 \mu \mathrm{g} / \mathrm{mL}$ (Nasrin, 2013). Study on another plant that contains quercetin like Babadotan has been done namely Moringa oleifera. The result showed that M. oleifera has antioxidant activity with a percentage of DPPH $\mathrm{IC}_{50}$ value $79 \pm 0.28 \mu \mathrm{g} / \mathrm{mL}$ (Alimsyah et al., 2020). According to the results, antioxidant activity of Babadotan was more active than $M$. oleifera.

In the anti-elastase test, BEE was compared to quercetin. Quercetin is one of the flavonoid class active substances that is reported to have elastase inhibitory activity (Xu et al., 2009). According to previous study, babadotan extract has high flavonoids content, especially quercetin. Quercetin is a flavonoid compound of the flavonol group that can have antioxidant activity in babadotan. Therefore, quercetin can be chosen as a comparison in this test. The quercetin content in babadotan ( $A$. conyzoides (L.) L.) is 209.622 ppm, which was obtained by digestion technique for two hours at $60^{\circ} \mathrm{C}$ using ethanol as a solvent (Tambunan et al., 2017; Thring et al., 2009).

Based on the result, BEE can inhibit the elastase but this activity was lower than quercetin. It is because quercetin used in this experiment is pure quercetin, while BEE is a thick extract obtained from the extraction using ethanol solvents. There are also other secondary metabolites contained in BEE. BEE has anti-elastase activity with $\mathrm{IC}_{50}$ value of $45.35 \pm 2.2 \mu \mathrm{g} / \mathrm{mL}$. Even though antielastase activity on BEE was lower than quercetin, there's study on another plant that contain quercetin. The study was based on M. oleifera plant and the antielastase activity of $M$. oleifera is $6.444 \pm 314.5 \mu \mathrm{g} / \mathrm{mL}$ (Alimsyah et al., 2020). It shows that the anti-elastase activity of BEE was more active than $M$. oleifera. 
The anti-collagenase activity assay showed that quercetin had a higher collagenase inhibitory activity compared to BEE because it was suspected that quercetin was a compound that has been proved to have anti-collagenase activity of $79.3 \pm 0.1 \mu \mathrm{g} / \mathrm{mL}$, according to previous study (Bougeois et al., 2016). A previous research showed that anti-collagenase activity of quercetin is caused by the role of antioxidants (Ozgen et al., 2016). Antioxidants can inhibit free radicals that activated collagenase, so antioxidants can be anti-collagenase. According to a study, flavonoids especially flavonol, can inhibit collagenase with $\mathrm{IC}_{50}$ of $286 \mu \mathrm{M}$, and quercetin is a flavonoid compound that has anti-collagenase activity (Sin \& Kim, 2005).

Based on the result, BEE has anti-collagenase activity with $\mathrm{IC}_{50}$ of $55.07 \pm 0.1 \mu \mathrm{g} / \mathrm{mL}$, it is suspected the anticollagenase activity is caused by the role of flavonoids found in BEE. According to previous study, BEE contains flavonoids, especially quercetin. Quercetin found in babadotan is quercetine-3-O-glycoside and quercetine-3-O-rutinoside (Tambunan et al., 2017). Study on $M$. oleifera, which contains quercetin like babadotan, has anti-collagenase activity of $47.25 \%$ (Nurulita et al., 2019). Babadotan has anti-collagenase activity of $44.01 \%$, a little lower than $M$. oleifera, but babadotan still can inhibit collagenase.

BEE, which contains quercetin, can prevent autooxidation by preventing the formation of peroxide radicals by fast-binding to radical compounds, so these radical compounds do not bind to oxygen. Quercetin binds to peroxide radicals that have been formed and stabilize them, so fast and chain auto-oxidation reactions can be inhibited. Quercetin will bind free radical species, so that it can reduce the reactivity of free radicals and inhibit anti-collagenase activity (Ikawati et al., 2008; Ozgen et al., 2016). In conclusion, BEE possesses antioxidant and antiaging activities that can prevent the aging process.

\section{CONCLUSION}

Phytochemical analysis of BEE showed the presence of flavonoids, alkaloids, tannins, polyphenols, quinones, steroids and triterpenoids, monoterpenoids and sesquiterpenoids, and the absence of saponins. BEE has lower activity on DPPH scavenging activity, elastase and collagenase inhibitory activity, if compared to quercetin. Overall, both BEE and quercetin possess antioxidant and antiaging activities.

\section{ACKNOWLEDGEMENTS}

This research was funded by Faculty of Pharmacy, University of Jenderal Achmad Yani, Cimahi-Bandung and Biomolecular \& Biomedical Research Center, Aretha Medika Utama, Bandung (AMU-BBRC). The laboratory facilities and research methodology were supported by AMU-BBRC. The authors like to thank to Cintani Dewi Wahyuni from AMU-BBRC for her technical assistances.

\section{REFERENCES}

Adam, R. S. H., Medan, M. (2005). Kulit Menua. 38(2). $1-5$.

Adnyana, I. K., Abuzaid, A. S., Iskandar, E. Y., \& Kurniati, N. F. (2016). Pancreatic lipase and $\alpha$-amylase inhibitory potential of mangosteen (Garcinia mangostana Linn.) pericarp extract. International Journal of Medical Research \& Health Sciences, 5(1), 23-28.

Afrianti, R., Nofiandi, D., Dira, D., \& Ulfa, W. (2016). Pengujian efektivitas penyembuhan luka mencit diabetes melitus yang diberikan sediaan krim ekstrak etanol daun bandotan. Scientia: Jurnal Farmasi dan Kesehatan, 6(1), 50-58.

Afrianti, R., Yenti, R., \& Monica, H. (2014). Pengamatan serabut kolagen pada proses penyembuhan luka dalam sediaan krim ekstrak etanol daun bandotan (Ageratum conyzoides L.). Perkembangan Terkini Sains Farmasi dan Klinik IV, 39, 40.

Alimsyah, F., Sugihartini, N., Susanti, H. (2020). Optimasi campuran ekstrak etanol buah pepaya (Carica papaya L.) dan ekstrak etanol daun kelor (Moringa oleifera) dalam krim sebagai antiaging. Jurnal Darul Azhar, 9(1), 23-29.

Amadi, B. A., Duru, M. K. C., \& Agomuo, E. N. (2012). Chemical profilesof leaf, stem, root and flower of Ageratum conyzoides. Asian Journal of Plant Science and Research, 2(4), 428-432.

Bera, T. K., Chatterjee, K., \& Ghosh, D. (2015). In-vitro antioxidant properties of the hydro-methanol extract of the seeds of Swietenia mahagoni (L.) Jacq. Biomarkers and Genomic Medicine, 7(1), 18-24.

Bougeois, C., Leclerc, E. A., Corbin, C., Doussot, J., Serrano, V., Vaier, J.R., Hano, C. (2016): L'ortie (Urtica dioica $\mathrm{L}$.), une source de produits antioxidants et phytochimiques anti-age pour des applications en cosmetique. Comptes Rendus Chimie,19(9), 1090-1100.

Cai, Y., Luo, Q., Sun, M., \& Corke, H. (2004). Antioxidant activity and phenolic compounds of 112 traditional Chinese medicinal plants associated with anticancer. Life Sciences, 74(17), 2157-2184. 
Farnsworth, N. R. (1966). Biological and phytochemical screening of plants. Journal of Pharmaceutical Sciences, 55(3), 243-264.

Galati, E. M., Miceli, N., Taviano, M. F., Sanogo, R., \& Raneri, E. (2001). Anti-inflammatory and antioxidant activity of Ageratum conyzoides. Pharmaceutical Biology, 39(5), 336-339.

Ikawati, M., Wibowo, A.E., Octa, N.S., \& Adelina, R.(2008): Pemanfaatan benalu sebagai agen antikanker. Laporan Penelitian, Fakultas Farmasi Universitas Gadjah Mada, Yogyakarta.

Irshad, M., \& Chaudhuri, P. S. (2002). Oxidantantioxidant system: role and significance in human body. Indian Journal of Experimental Biology, 40(11), 12331239

Kim, J.H., Cho, Y.H., Lee, B.C., \& Pyo, H.B. (2007): Cosmetic Composition Comprising Extracts of Pterocarpus santalinus Capable of Inhibiting Activity. Korea Patent.

Mohandas, G.G., Kumaraswamy, M. (2018) Antioxidant activities of terpenoids from Thuidium tamariscellum (C. Muell.) Bosch. and Sande-Lac. a Moss. Pharmacognosy Journal, 10(4), 645-649

Mukherjee, P. K., Maity, N., Nema, N. K., \& Sarkar, B. K. (2011). Bioactive compounds from natural resources against skin aging. Phytomedicine, 19(1), 64-73.

Nasrin, F. (2013). Antioxidant and cytotoxic activities of Ageratum conyzoides stems. International Current Pharmaceutical Journal, 2(2),33-37.

Nurulita, N.A., Sundhani, E., Amalia, I., Rahmawati, F., \& Utami, N.N.D. (2019). Uji aktivitas antioksidan dan anti-aging body butter dengan bahan aktif ekstrak daun kelor. Jurnal Ilmu Kefarmasian Indonesia, 17(1),1-8.

Ozgen, S., Kilinc, O. K., \& Selamoğlu, Z. (2016). Antioxidant activity of quercetin: A mechanistic review. Turkish Journal of Agriculture-Food Science and Technology, 4(12), 1134-1138.

Sin, B. Y., \& Kim, H. P. (2005). Inhibition of collagenase by naturally-occurring flavonoids. Archives of Pharmacal Research, 28(10), 1152-1155.

Sohn, D. H., Kim, Y. C., Oh, S. H., Park, E. J., Li, X., \& Lee, B. H. (2003). Hepatoprotective and free radical scavenging effects of Nelumbo nucifera. Phytomedicine, 10(2-3), 165-169.
Tambunan, A. P., Bahtiar, A., \& Tjandrawinata, R. R. (2017). Influence of extraction parameters on the yield, phytochemical, TLC-densitometric quantification of quercetin, and LC-MS profile, and how to standardize different batches for long term from Ageratum conyoides L. leaves. Pharmacognosy Journal, 9(6),767-774

Taniguchi, M., Arai, N., Kohno, K., Ushio, S., \& Fukuda, S. (2012). Anti-oxidative and anti-aging activities of 2-O- $\alpha$-glucopyranosyl-L-ascorbic acid on human dermal fibroblasts. European Journal of Pharmacology, 674(23), 126-131.

Thring, T. S., Hili, P., \& Naughton, D. P. (2009). Anticollagenase, anti-elastase and anti-oxidant activities of extracts from 21 plants. BMC complementary and Alternative Medicine, 9(1), 27.

Utami, S., Sachrowardi, Q. R., Damayanti, N. A., Wardhana, A., Syarif, I., Nafik, S., Arrahman, B.C., Kusuma, H.S.W \& Widowati, W. (2018). Antioxidants, anticollagenase and antielastase potentials of ethanolic extract of ripe sesoot (Garcinia picrorrhiza Miq.) fruit as antiaging. Journal of Herbmed Pharmacology, 7(2),8893

Widowati, W., Fauziah, N., Herdiman, H., Afni, M., Afifah, E., Kusuma, H.S.W, Nufus, H., Arumwardana, S., \& Rihibiha, D.D. (2016). Antioxidant and anti aging assays of Oryza sativa extract, vanillin and coumaric acid. Journal of Natural Remedies, 16(3), 88-99.

Widowati, W., Rani, A.P., Hamzah, R.A., Arumwardana, S., Afifah, E., Kusuma, H.S.W., Rihibiha, D.D., Nufus, H.,\& Amalia, A. (2017). Antioxidant and antiaging assays of Hibiscus sabdariffa extract and its compounds. Natural Product Sciences, 23(3),192-200.

Widowati, W., Janeva, B.W., Nadya, S., Amalia, A., Arumwardana, S., Kusuma, H.S.W., \& Arinta, Y. (2018). Antioxidant and antiaging activities of Jasminum sambac extract, and its compounds. Journal of Reports in Pharmaceutical Sciences, 7(3), 270-285

Wiedow, O., Wiese, F., \& Christophers, E. (1995). Lesional elastase activity in psoriasis. Archives of Dermatological Research, 287(7), 632-635.

Wuyep, P.A., Musa, H.D., Ezemokwe, G.C., Nyam, D.D., \& SilaGyang, M.D. (2017). Phytochemicals from Ageratum conyzoides L. extracts and their antifungal activity against virulent Aspergillus spp. Journal of Academia and Industrial Research, 6(3),32-39. 
Xu, G.H., Ryoo, I.J., Kim, Y.H., Choo, S.J., \& Yoo, I.D. (2009). Free radical scavenging and antielastase activities of flavonoids from the fruits of Thuja orientalis. Archives of Pharmacal Research, 32(2), 275282. 